\title{
Mapping Out a Strategy for Synergizing Science and Technology Institutions and Industries in Research and Skill Development in Nigeria
}

\author{
Shehu Abdullahi Ma'aji \\ Department of Industrial and Technology Education, \\ Federal University of Technology, Minna, \\ Niger State, NIGERIA \\ abdullahimaaji@futminna.edu.ng
}

\begin{abstract}
The significance of partnership between training institutions of higher institutions of learning and productive sector (industries) is to enable Nigeria use Research and Development related Science, Technology and Innovation as the fundamental ingredients to enhance its competitiveness and advance itself into the grouping of industrialized countries by the year 2020. Thereby, promoting Small and Medium Enterprises (SMEs), training and retraining, citizens will be empowered to be productive, to think, to be creative, to innovate and to generate wealth for Nigeria's development. The study was a survey research in which data was collected through a 50 items questionnaire on a population of 300 respondents purposively sampled from six (6) geo-political zones of Nigeria (18 Higher Institutions of Learning and 18 Industries). Data collected from the research questions were analysed using Mean and Standard Deviation on a 5-point likert-type scale, while t-test was used to test the null hypothesis at .05 level of probability. Findings of the study revealed among others that the institutions do not have synergy with industries in research and development despite provision available; as a result most of the higher institutions find it difficult to collaborate with industries in Research, Development and Skill acquisition for Industrial Development in Nigeria. The study recommended among others, that there should be a synergy, collaboration and partnership in Research and Skill Development between higher institution and industries. The study also suggested that Government should build a National Laboratory/Workshop Park for STI related to R\&D for institutions and industries which will be fully equipped with state of the art science and technology equipment which would serve as a research house, or known as "Super labs" or "Central Sharing Facility Centre" for common use.
\end{abstract}

Index Terms - Research \& Development (R\&D); Science, Technology and Innovation (STI), Small and Medium Enterprises (SMEs)

\section{Introduction}

A key ingredient for creating wealth and promoting sustainable human development is access to and dissemination of scientific and technological knowledge. Science, Technology and Innovation (STI) are widely seen as dominant factors behind rapid economic and industrial growth. Globally, newly industrialized countries have had to master the use of imported and indigenous technology in order to achieve economic development so as to at par with the developed countries. Countries with high growth rates use technological means to export a strong mix of value added goods and services. Their private sectors invest aggressively in technology, research, development and innovation, supported and encouraged by government as well as industries. Their educational systems produce large number of scientists and technologists who find profitable employment. Wealth and job creation depend on the application of new technology and a well trained and adaptive citizenry to keep established industries competitive, as well as the development and growth of knowledge-based industries [1] [2]

The African Development Bank stressed that high economic growth rates have been achieved in countries such as Singapore, Brazil, Finland and Korea, because they have invested heavily in Research and Development (R\&D) related to STI [3]. According to the Organisation for Economic Co-operation and Development (OECD, 2003), all technological innovations can be traced back, at least in part, to Science and Engineering. It is safe to conclude that in today's social structure, STI have a pivotal role to play [4]. Government officials, policy analysts, economists, and corporate Chief Executive Officers in Nigeria and beyond closely follow Science and Technology changes, continuously evaluate its impact, and try to position their respective countries and institutions such that they will benefit from what has become to be known as "having the competitive edge".

UNESCO revealed in its annual report that Nigerian Scientists and Engineers are improving their understanding on relevant policy issues such as climate change, growth in resource consumption rates, demographic trends, and environmental degradation [5]. It was further declared that changes in these and other areas need to be taken into account in devising long-term strategies for development. Scientific knowledge is being applied to assess current conditions and future prospects in relation to sustainable development. Ignoring S\&T is detrimental, be it by Governments, academics, or industry leaders. It is this powerful force that has claimed the attention of some of the best minds during the past few decades. Understanding the process of scientific and technological change, measuring it, promoting it, and using it to the public's or one's own advantage has been the subject of study and deliberation of a large number of researchers.

Research and Development (R\&D) is held to be by all nations the most renowned activity that has as its explicit goal: the ability to increase scientific knowledge. In 
developed countries, the media reports and analyses R\&D. Business magazines regularly publish data regarding $R \& D$ investment by firms [6]. Stock exchanges react to R\&D investment and planning. More and more, corporations are considering R\&D data in their long term planning. Administrations concerned with economic growth and productivity rely on $R \& D$ statistics as one possible type of indicator of technological change. Abdullahi pointed out that R\&D statistics are now essential background element in many government programmes and provide an important tool for evaluating them. Scientists and engineers are considered as the key performers of $R \& D$, aimed at increasing the stock of knowledge and devising new applications in order to ensure sustainable development. But in addition to $R \& D$, there are many other avenues of increasing the pool of knowledge and these are part of the innovative process. Scientific knowledge may be brought into a firm, an industry, or a country by purchasing, or licensing patents. Firms may also acquire new knowledge by non-market mechanisms, for instance, searching public information systems. New knowledge can also be imported in the form of embedded knowledge in machinery, methods, processes and procedures that are purchased. That is, the purchase of technology intensive capital goods will bring embedded knowledge to the buyer.

The application of scientific approaches and innovation in state enterprises such as the utilities, security and health services can foster a better quality of life for citizens. Similarly, the harnessing of scientific and technological resources to better understand and treat environmental resource issues, pollution, development projects etc. particularly as they impact on land and marine resources, can lead to a better environment for present and future generations.

\section{Significance of the Study}

The significance of partnership between training institutions of higher learning/research institutions and productive sector (industries) is to enable Nigeria use R\&D related STI as the fundamental ingredients to enhance its competitiveness and advance itself into the grouping of industrialized countries by the year 2020 . STI will be used to create new wealth through the balanced and sustainable $\mathrm{R} \& \mathrm{D}$ of all its key sectors in order to ensure prosperity, the alleviation of poverty and unemployment and the improvement in the physical, social and cultural well-being of all Nigerians. By promoting Small and Medium Enterprises (SMEs), training and retraining, citizens will be empowered to be productive, to think, to be creative, to innovate and to generate wealth for Nigeria's development.

\section{Research Questions}

Three research questions were formulated to guide the study:

1. How adequate are the laboratories and workshops for conducting R\&D related to STI in higher institutions of learning and industries.

2. Is there any linkage/partnership relationship between higher institutions of learning and industries in $R \& D$ activities?
3. What are the strategies for linking higher institutions of learning and industries partnership in $R \& D$ related to STI for national development?

\section{Methodology \\ a) Research Design}

The study was conducted using survey research design. This was used because it gives the most appropriate outline or plan for data collection from the respondents. The survey design concept was considered best because of the nature of information required and the source of information to be reached. Therefore, the survey was used to reach-out all the targeted populations at their different geographical locations to collect data intended for the study.

\section{b) Population}

The targeted population for the study was the entire staff of higher institutions of learning and major industries relevant to STI in their activities. The population was identified based on their relevance with the objective of the study (Science, Technology and Innovation - STI). The list of identified institutions of higher learning and industries was captured in 'appendix A'. The population was finally sampled due to its large size and geographical location spread across the country.

\section{c) Sample and Sampling Techniques}

The sample size for the study was determined from the population of the study. There was no statistical formula used, rather all institutions of higher learning and major industries that have relevance with STI were pooled out as sample from the population. However, sampling techniques used was by using 6-geopolitical zone distribution of administrative state in the country. Nigeria has thirty-six (36) states and Abuja, Federal Capital Territory.

TABLE I.

List OF SIX (6) GEO-POLITICAL ZONE DistribUTION IN Nigeria

\begin{tabular}{|c|c|c|}
\hline S/No & $\begin{array}{l}\text { Geo-Political } \\
\text { Zone }\end{array}$ & States \\
\hline 1 & North-Central & $\begin{array}{l}\text { Benue, Kogi, Kwara, Nasarawa, Niger, } \\
\text { Plateau, and Federal Capital Territory, } \\
\text { Abuja }\end{array}$ \\
\hline 2 & North-Eastern & $\begin{array}{l}\text { Adamawa, Bauchi, Borno, Gombe, } \\
\text { Taraba and Yobe }\end{array}$ \\
\hline 3 & North-Western & $\begin{array}{l}\text { Jigawa, Kaduna, Kano, Katsina, Kebbi, } \\
\text { Sokoto and Zamfara }\end{array}$ \\
\hline 4 & South-Eastern & Abia, Anambra, Ebonyi, Enugu, and Imo \\
\hline 5 & South-South & $\begin{array}{l}\text { Akwa Ibom, Bayelsa, Cross River, Delta, } \\
\text { Edo and Rivers. }\end{array}$ \\
\hline 6 & South-Western & Ekiti, Lagos, Ogun, Ondo, Osun and Oyo \\
\hline
\end{tabular}

Therefore in each of these states some institutions of higher learning and industries relevant to STI were sampled where available on the basis of strata. That is institutions with bias in science and technology while the industries were based on their production, for example: processing, production and manufacturing activities. They were grouped and sampled as indicated table 2 below. 
TABLE II.

LIST OF SELECTED HIGHER INSTITUTIONS OF LEARNING AND INDUSTRIES

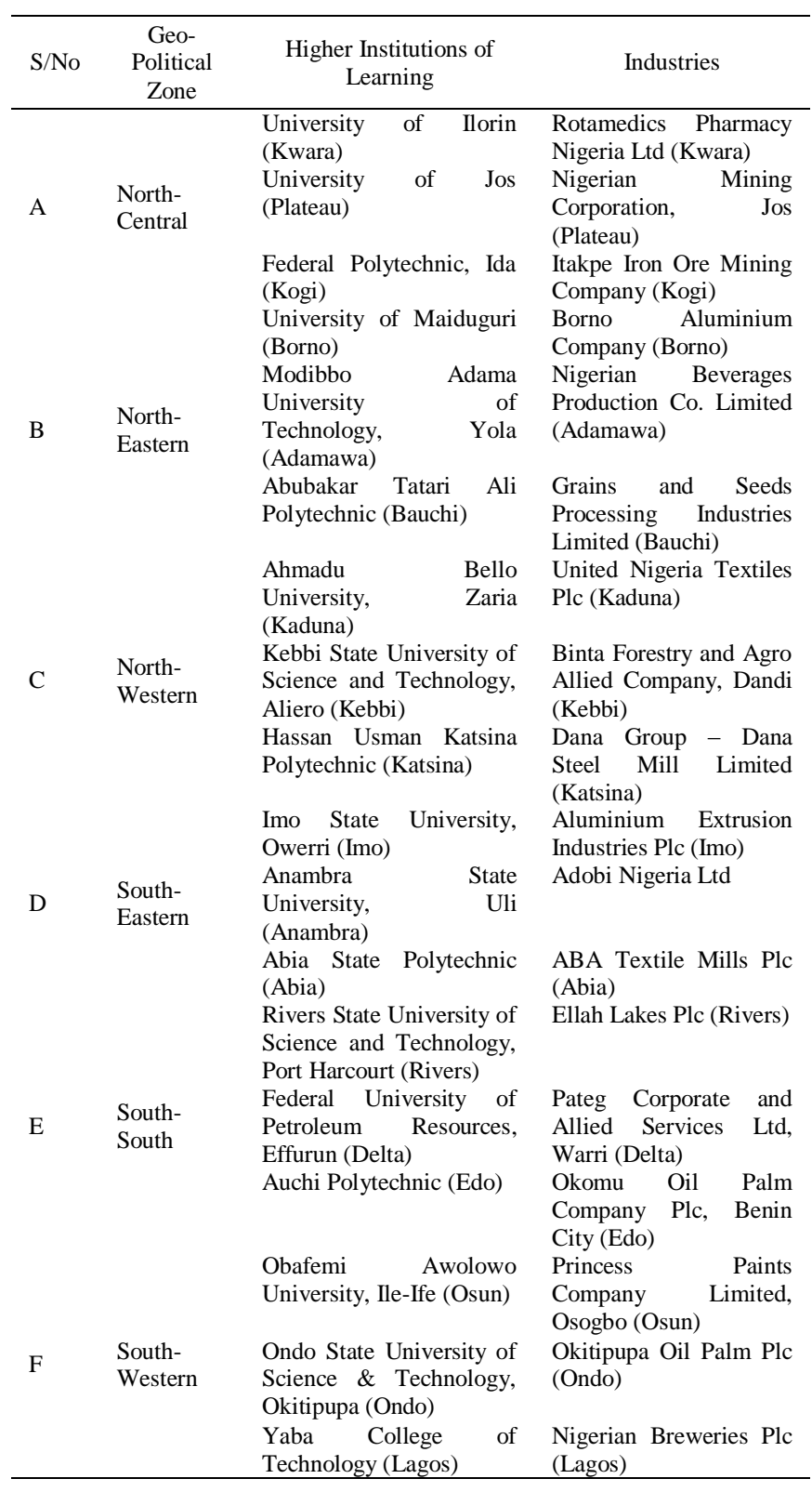

\section{Data Collection}

Data are the nucleus of every scientific study. Therefore, appropriate instrument for data collection was developed and used known as "Questionnaire". The questionnaire was carefully designed and distributed to the respondents for data collection in accordance with the purpose of the study at various areas with a several followup for clarification of some areas of the questionnaire found difficult to answer and retrieved the same number or little less for analysis. Two separate questionnaires were developed; one for industries and the other for higher institutions of learning addressing the three (3) areas of research questions.

\section{Research Analysis and Findings}

TABLE III.

RESULTS OF DATA ANALYSIS ON HIGHER INSTITUTIONS OF LEARNING (SCIENCE AND TECHNOLOGY) IN NIGERIA

\begin{tabular}{|c|c|c|c|c|}
\hline \multirow{2}{*}{$\begin{array}{l}\text { Geo- } \\
\text { Political } \\
\text { Zone }\end{array}$} & \multirow{2}{*}{$\begin{array}{l}\text { Higher Institutions of } \\
\text { Learning }\end{array}$} & \multicolumn{2}{|c|}{$\begin{array}{l}\text { Lab./Workshop } \\
\text { Facilities }\end{array}$} & \multirow{2}{*}{$\begin{array}{l}\text { Linkage/P } \\
\text { artnership } \\
\text { Provision }\end{array}$} \\
\hline & & Lab. Fac. & $\begin{array}{l}\text { W/shop } \\
\text { Fac. }\end{array}$ & \\
\hline \multirow{3}{*}{$\begin{array}{l}\mathrm{A}= \\
\text { North- } \\
\text { Central }\end{array}$} & $\begin{array}{l}\text { University of Ilorin } \\
\text { (Kwara) }\end{array}$ & Adequate & Adequate & Available \\
\hline & $\begin{array}{l}\text { University of Jos } \\
\text { (Plateau) }\end{array}$ & Adequate & Adequate & Available \\
\hline & $\begin{array}{l}\text { Federal Polytechnic, Ida } \\
\text { (Kogi) }\end{array}$ & $\begin{array}{l}\text { Fairly } \\
\text { Adequate }\end{array}$ & Adequate & Available \\
\hline \multirow{3}{*}{$\begin{array}{l}\mathrm{B}= \\
\text { North- } \\
\text { Eastern }\end{array}$} & $\begin{array}{l}\text { University of Maiduguri } \\
\text { (Borno) }\end{array}$ & $\begin{array}{l}\text { Fairly } \\
\text { Adequate }\end{array}$ & $\begin{array}{l}\text { Fairly } \\
\text { Adequate }\end{array}$ & $\begin{array}{l}\text { Not } \\
\text { Available }\end{array}$ \\
\hline & $\begin{array}{l}\text { Modibbo Adama } \\
\text { University of Technology, } \\
\text { Yola (Adamawa) }\end{array}$ & Adequate & $\begin{array}{l}\text { Fairly } \\
\text { Adequate }\end{array}$ & Available \\
\hline & $\begin{array}{l}\text { Abubakar Tatari Ali } \\
\text { Polytechnic (Bauchi) }\end{array}$ & $\begin{array}{l}\text { Fairly } \\
\text { Adequate }\end{array}$ & $\begin{array}{l}\text { Inadequat } \\
\mathrm{e}\end{array}$ & $\begin{array}{l}\text { Not } \\
\text { Available }\end{array}$ \\
\hline \multirow{3}{*}{$\begin{array}{l}\mathrm{C}= \\
\text { North- } \\
\text { Western }\end{array}$} & $\begin{array}{l}\text { Ahmadu Bello University, } \\
\text { Zaria (Kaduna) }\end{array}$ & Adequate & Adequate & Available \\
\hline & $\begin{array}{l}\text { Kebbi State University of } \\
\text { Science and Technology, } \\
\text { Aliero (Kebbi) }\end{array}$ & $\begin{array}{l}\text { Fairly } \\
\text { Adequate }\end{array}$ & Adequate & Available \\
\hline & $\begin{array}{l}\text { Hassan Usman Katsina } \\
\text { Polytechnic (Katsina) }\end{array}$ & Adequate & $\begin{array}{l}\text { Fairly } \\
\text { Adequate }\end{array}$ & Available \\
\hline \multirow{3}{*}{$\begin{array}{l}\mathrm{D}= \\
\text { South- } \\
\text { Eastern }\end{array}$} & $\begin{array}{l}\text { Imo State University, } \\
\text { Owerri (Imo) }\end{array}$ & Adequate & Adequate & Available \\
\hline & $\begin{array}{l}\text { Anambra State } \\
\text { University, Uli (Anambra) }\end{array}$ & Adequate & $\begin{array}{l}\text { Fairly } \\
\text { Adequate }\end{array}$ & Available \\
\hline & $\begin{array}{l}\text { Abia State Polytechnic } \\
\text { (Abia) }\end{array}$ & Adequate & $\begin{array}{l}\text { Fairly } \\
\text { Adequate }\end{array}$ & Available \\
\hline \multirow{3}{*}{$\begin{array}{l}\text { E = } \\
\text { South- } \\
\text { South }\end{array}$} & $\begin{array}{l}\text { Rivers State University of } \\
\text { Science and Technology, } \\
\text { Port Harcourt (Rivers) }\end{array}$ & Adequate & Adequate & Available \\
\hline & $\begin{array}{l}\text { Federal University of } \\
\text { Petroleum Resources, } \\
\text { Effurun (Delta) }\end{array}$ & Adequate & Adequate & Available \\
\hline & Auchi Polytechnic (Edo) & Adequate & Adequate & Available \\
\hline \multirow{3}{*}{$\begin{array}{l}\mathrm{F}= \\
\text { South- } \\
\text { Western }\end{array}$} & $\begin{array}{l}\text { Obafemi Awolowo } \\
\text { University, Ile-Ife (Osun) }\end{array}$ & Adequate & Adequate & Available \\
\hline & $\begin{array}{l}\text { Ondo State University of } \\
\text { Science \& Technology, } \\
\text { Okitipupa (Ondo) }\end{array}$ & Adequate & Adequate & Available \\
\hline & $\begin{array}{l}\text { Yaba College of } \\
\text { Technology (Lagos) }\end{array}$ & Adequate & Adequate & Available \\
\hline
\end{tabular}

\section{Findings}

Based on the data collected and analysed on Higher Institutions of Learning and Research Institutes, the following findings were made:

1. Most of the institutions have laboratories and workshops and are adequately equipped with modern facilities except Abubakar Tatari Ali Polytechnic (Bauchi) which needs modern laboratories with state of the art facilities. But majority needs to be improved.

2. All the institutions under the study have a strong foundation for Applied Science, Pure Science, and Engineering and Technology based programmes for local, regional and international research capabilities.

3. Most of the institutions have experts and provision courses for linkage and partnership but lack strong coordination for collaboration, linkage or affiliation for innovative research for regional or at international level.

4. Most of the institutions were just setting research boards and commissions for the take-off of research activities in their schools. 
5. Therefore, relationship between institution and relevant industries of their programmes/activities was not sufficiently pursued.
6. There were potential research interest areas for national development in the institutions but were not harnessed.

TABLE IV.

RESULTS OF DATA ANALYSIS ON INDUSTRIES (SCIENCE AND TECHNOLOGY) IN NIGERIA

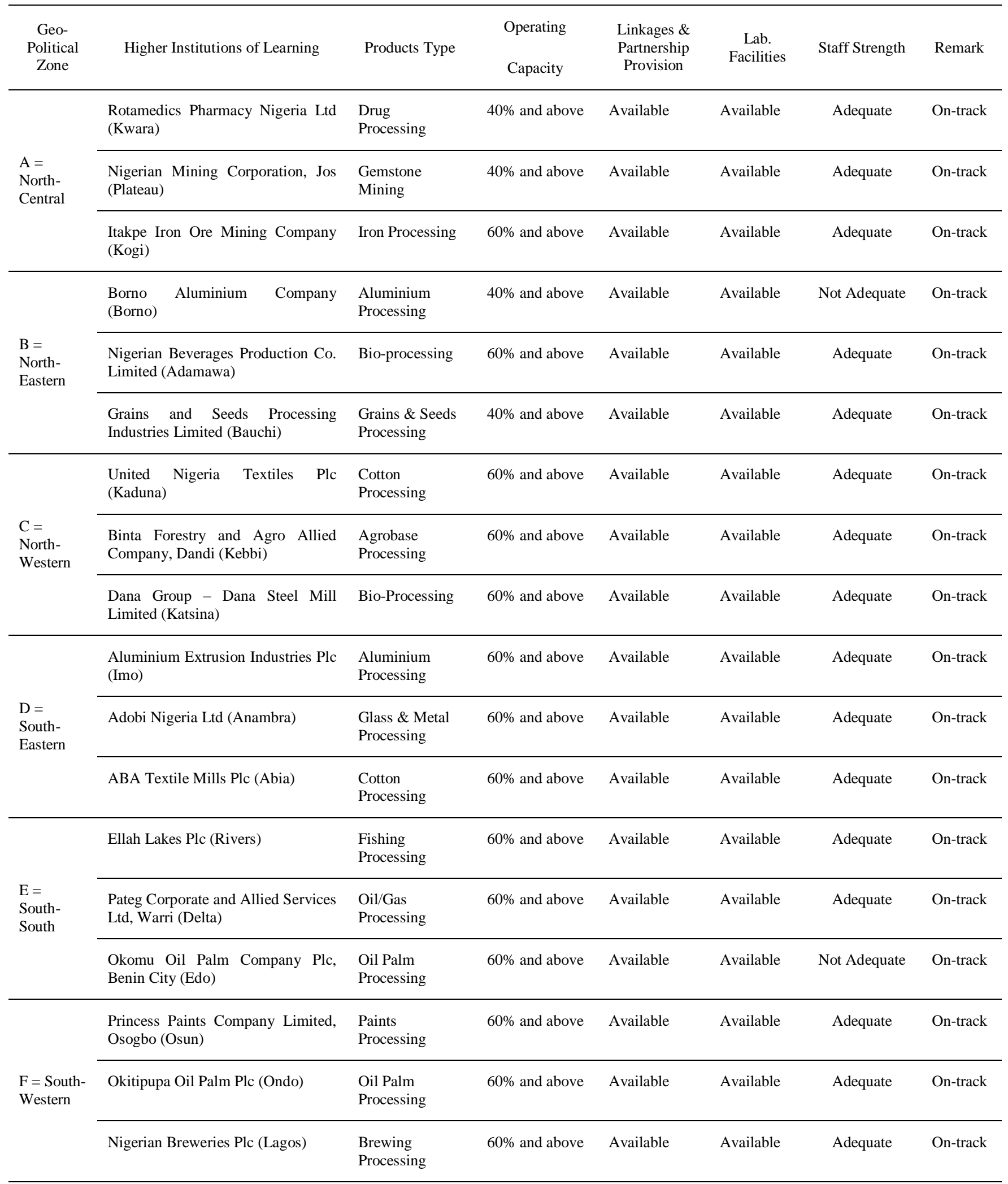


Based on the data collected and analysed on industries, the following findings were made:

The eighteen industries used in this study were Processing-based different products ranging from Aluminum, Cotton, Gemstone, Fishing, Oil-palm, Oil-gas, Brewing etc. Fourteen out of Eighteen of these industries maintain sixty percent $(60 \%)$ and above operating capacity with above average level of Engineers, Researchers/Assistant, Technicians and Technologists handling and maintaining the day to day activities of their industries. The remaining four (4) industries are Rotamedics Pharmacy Nigeria Ltd, Nigerian Mining Corporation Jos, and Borno Aluminium Company are above $40 \%$.

All the Eighteen (18) Processing-based industries declare interest for partnership/linkage programme with full support. Also, this option indicates the availability of laboratory facilities in the industries for Research and Development except two (2) industry (i.e. Borno Aluminium Company and Okomu Oil Palm Company Plc, Benin City) that has inadequate or unavailability of laboratory. Some of the Industries are already in partnership with other Agricultural Organisations in development areas of their products. The weakness demonstrated by this group is inadequate or absence of specific budgetary allocation committed to research and development to their products. Most of these industries have quality control laboratory only.

\section{General Mapping Strategies for Linking Higher Institutions of Learning and Industries Partnership in R\&D Related To STI}

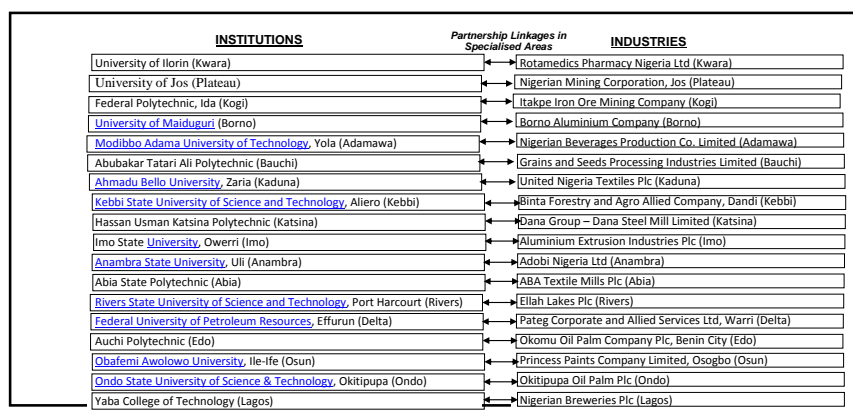

Fig. 1. Mapping Out Institution and Related Industry

Fig. 1 above shows the eighteen (18) higher institutions of learning has faculties in relevant to STI and capable of conducting $\mathrm{R} \& \mathrm{D}$ in various disciplines. The figure also identifies related industries that have potentials for carrying out meaningful research activities in partnership with the university/polytechnic.

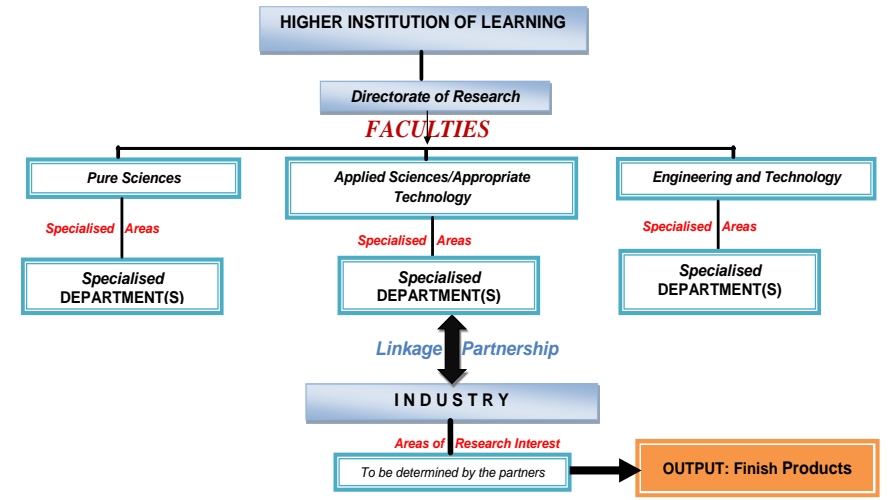

Fig, 2. Direct Mapping Out Strategies between Higher Institutions of Learning and Related Industries

Fig. 2 above demonstrated direct mapping strategies and guide between higher institutions of learning and related industries. More so, it was revealed that some industries can be fixed to work with other faculties other than where they were identified with, depending on their areas of research interest. The technical problem that was identified for the success of this linkage which needs attention is the "improvement in laboratory facilities" in the industries where the research would likely be conducted. Other problems may be tackled administratively by the coordinating body or by a carefully designed follow-up study.

\section{Recommendations and Way Forward}

The key to sustained growth in Nigeria will be to put in place the infrastructure and the environment, as well as the incentives for long-term development that is "mapping science, technology and innovation for industrial development in Nigeria through linking research and development between industries and higher learning institutions". STI is a vehicle which will advance the need for satisfying the basic requirements of the people of Nigeria for food, shelter, clothing, health, education and wealth creation. Nigeria must therefore embark on a mission to embrace technology transfer, absorption, adaptation and innovation for the purpose of creating sustainable growth and competitive industries and improving the quality of life of its citizens.

\section{a) General Recommendations}

The study recommends in line with its findings that: participation in the global economy will require increased use of scientific and technical knowledge. Technological innovation and the associated institutional adjustments underpin long-term growth and must be at the centre of any strategy to strengthen both public and private sector.

\section{b) Recommendations to Government of Nigeria}

The role of government in the mapping science and technology for industrial development in Nigeria through linking research and development between industries and higher learning institutions can not be overemphasised; 
therefore, the following recommendations were made as a result of the findings of this study;

1. Personnel: The government of Nigeria need to ensure that education in Science, Technology and Innovation fulfils the technical skills needs for STI Industries. Incentives should be provided by the government of Nigeria to stimulate the development of Science and Technology skills personnel in industries and institutions focusing on the following areas:

- motivating young people to excel in STI Studies;

- building a core of well qualified and competent S\&T personnel in each Ministry and throughout each economic sector;

- ensuring the motivation of well qualified STI teachers and lecturers at all levels of education;

- incentive schemes for the promotion of innovative, entrepreneurial activities, with special emphasis on all industries and institutions;

- incentives to empower women to participate fully in STI development and management;

- Generally, to facilitate the promotion of qualified and skilled Nigerians in all fields of STI.

- Finally, the government needs to affirm the importance of partnerships between government, institutions, industries and donors such as (AfDB, UNESCO, World Bank etc). A horizontal coordination between different actors should be established, and, through decentralisation processes, there should be effective vertical links between central government, local government and institutions/industries;

2. Laboratory/Workshop Facilities:- Government need to build a National Laboratory/Workshop Park for STI related to R\&D for institutions and industries which will be fully equipped with state of the art science and technology equipment; this include modern facilities and machines related to STI for R\&D. This would serve as a research house where institutions and industries without adequate workshops/laboratory facilities can make use of it, or known as "Super labs" or "Central Sharing Facility Centre" for common use.

3. Research Funds:- There is a need for Government to develop ways, means and special programmes to generate and fund STI and facilitate good R\&D activities. This will ensure a predictable stream of both public and private funds. Public - private sector cooperation is essential to ensure funds are used effectively and achieve specific STI objectives.

4. Provision of Partnership:- Government of Nigeria need to employ positive partnership strategies. Industries and Institutions development through map-out is not simply about bringing international firms or investors into the country for specific project partnerships, but is more pervasive in building a partnership relationship within and outside the country that does not separate the acquisition of STI related to R\&D knowledge, problem solving of major issues, and income generation, but links the three in its strategies and policies.

\section{c) Recommendations to Higher Institutions of Learning of Nigeria}

The role of STI institutions in the mapping of science and technology for industrial development in Nigeria through linking research and development between industries and higher learning institutions cannot be overemphasized; therefore, the following recommendations were made as a result of the findings of this study;

1. Personnel: The institutions under the study need to improve the quality and quantity number of their staff personnel. All the institutions of higher learning, lecturers are teaching and at the same time researchers. It was noticed however that, adequate time cannot be devoted to research because the lecturers/teachers are overburdened with many teaching hours and hence have little time to concentrate on high quality research. Therefore, effort should be made to improve the number of Researchers and Lecturers as well.

2. Laboratory/Workshop Facilities:- There is a general outcry of inadequate facilities and equipment in some of the laboratories and workshops. Therefore, Institutions should challenge their final year students by encouraging and enforcing them to come up with practical project related to STI before graduation through professional supervision; This practical projects should be kept in the General Laboratory/Workshop and put in to use by the institutions during research. There should be an internal self-evaluation mechanism within the Institution to monitor Lab./Workshop facilities in compliance with minimum standards requirement on continuous basis to meet accreditation demands.

3. Research Funds:- There is a need for the Institution to develop ways, means and special programmes to fund STI and facilitate good R\&D research. This can be achieved through encouraging partnership from NGOs, foreign agencies and donors to support and provide them with research funds in areas of STI. Public - private sectors co-operation should also be sourced and ensure that funds are used effectively and achieve specific STI objectives.

4. Provision of Partnership:- The selected Institutions and industries for this study need to be devoted to the creation of R\&D partnership within themselves in order to achieve STI objectives; through joint STI research between Academics/Researchers. The Institutions should endeavour to foster a culture of partnership and strategic purpose among themselves and STI industries, and to 
link their service to STI providers, purchasers, users and consumers for meaningful added value goods and services. This is with the intention to provide greater job opportunities, sustainable earnings and rising living standards.

\section{d) Recommendations to STI Industries of Nigeria}

1. Personnel: There is need for increase in the quality and quantity of Scientists and Engineers in all the Industries particularly Industries found operating below 50\%; this can be achieved through retaining graduating students under attachment and sponsoring their scientist and engineers for high-level STI research. Staff should be advised to engage themselves and participate actively in the R\&D through collaboration internally and externally. This is one of the best ways to transfer technology and spread technological awareness regarding STI within industrial personnel and in developing country like Nigeria.

2. Laboratory/Workshop Facilities:- There is need for the introduction of modern laboratory/workshop facilities for R\&D specifically state of the art technology facilities. Industries should upgrade the state of their laboratories and workshops facilities to standard beyond ordinary quality control laboratory; this will enable R\&D activities add value to their goods and services.

3. Research Funds:- All the industries under the study should set aside $1 \%$ of their turn-over of the year for linking $R \& D$ activities.

4. Provision of Partnership:- Industries should source for more global and local partnership not only with higher learning institutions but with other developed industries that have both explicit and implicit scientific and technological objectives. The ability of all the industries (under this study) to participate in the global operating system will depend, to a large extent, on their capacity to generate new products through STI and enhance their competitiveness. Therefore, Domestic and International partnerships between Industry and Institutions of Higher Learning involving industrial personnel should be encouraged; this could also play an important role in spreading the benefits of emerging technologies.

\section{References}

[1] National Institute of Higher Education Research Science and Technology (NIHERST) [2002]. Human Resources in Science and Technology in the Public Sector: African Reporters, 2005-2010. Port of Spain, Trinidad: NIHERST.

[2] National Institute of Higher Education Research Science and Technology (NIHERST) [2002]. Survey of the Profile of Teachers In Public Secondary Schools: African Reporters, 1999-2004. Port of Spain, Trinidad: NIHERST.
[3] African Development Bank (AfDB) [2009]. Mapping Science and Technology for Industrial Development in Rwanda: Linking Research and Development between Industries and Higher Learning Institutions for Industrial Development.

[4] Organisation for Economic Co-operation and Development (OECD) [2003]. Science, Technology and Industry Scoreboard 2003 Highlights.

oecd.org/document/21/0,2340,en_2649_33703_16683413_1_ 1_1_1,00.html

[5] United Nations Educational, Scientific and Cultural Organization (UNESCO) [2011] Institute for Statistics, 2010. Website: http://www.uis.unesco.org/

[6] Abdullahi, S.A. (2013). Technical Report on Economic and Sector Work, Developing Science, Technology and Innovation: The Case of Nigeria. Human Development Department, African Development Bank (AfDB). Tunis: AfDB Publishers. 
